\title{
THE HYPERMOBILITY SYNDROME* MUSCULOSKELETAL COMPLAINTS ASSOCIATED WITH GENERALIZED JOINT HYPERMOBILITY
}

\author{
BY \\ J. A. KIRK, B. M. ANSELL, AND E. G. L. BYWATERS \\ From the M.R.C. Rheumatism Research Unit, Taplow, and the Department of Medicine, \\ Hammersmith Hospital, London
}

This paper is concerned with generalized joint laxity occurring as an isolated finding in otherwise normal subjects. We have used the name "Hypermobility Syndrome" for the situation in which this joint laxity is associated with musculoskeletal complaints. The range of joint motion varies considerably between individuals and with age, race, and body build. Where the joints are unduly lax and the range of motion is in excess of the accepted normal in most of the joints examined, we regard the subject as having generalized hypermobility. This is not uncommon in the general population. In their sample of 285 English schoolchildren, Carter and Wilkinson (1964) found excessive motion in at least four joint pairs in 7 per cent. and Sutro (1947) had shown that three or more joint pairs were hypermobile in 4 per cent. of 435 adult orthopaedic outpatients.

Information on this condition as a cause of musculoskeletal complaints is scanty. In the first detailed report, Key (1927) described a family in which the father and several sons were hypermobile because of generalized ligamentous laxity. Relatively little disability resulted except that recurrent patellar dislocation occurred in a son and the father had developed osteo-arthritic changes in the knees, spine, and fingers by the age of 50 with a resulting reduction in mobility. The first case of congenital hypermobility of joints as an isolated phenomenon producing chronic recurrent symptoms to be recognized by one of us (E.G.L.B., 1950) has unfortunately been lost to follow up.

Rowatt Brown and Rose (1966) have recently drawn attention to ligamentous laxity as one of the causes of precocious osteo-arthritis.

Most reports have noted a strong familial tendency (Finkelstein, 1916; Key, 1927), the inheritance being apparently dominant with a variable degree of expression (Sturkie, 1941).

\footnotetext{
* Read at a meeting of Heberden Society on June 17, 1967.
}

Massie and Howorth (1951) recognized the aetiological importance of generalized joint laxity in the pathogenesis of congenital dislocation of the hip. In their studies of recurrent patellar and shoulder dislocation and congenital hip dislocation, Carter and Sweetnam $(1958,1960)$ and Carter and Wilkinson (1964) showed a close association with familial joint laxity, particularly where the dislocation also occurred in close relatives.

Hass and Hass (1958) described a severe degree of joint laxity in five infants leading to postural foot deformities, scoliosis, and hip and elbow dislocations. Naming the condition arthrochalasis multiplex congenita, these authors recognized the entity of joint hypermobility without skin abnormality as an independent articular disorder from the EhlersDanlos syndrome.

One of the few previous reports of isolated hypermobility as a cause of recurrent joint pain and effusion was that of Sutro (1947) who described thirteen young adults with pain and effusions in the knees or ankles developing in the course of military training. The family histories were negative and the majority were unaware of being hypermobile. As these patients were soon discharged from the army, the outcome of their complaints was not known. Generalized joint laxity is also a feature of the hereditary connective tissue disorders, Marfan's syndrome, the Ehlers-Danlos syndrome, and osteogenesis imperfecta (McKusick, 1966). In the Achard syndrome it is prominent in the hands and feet in association with arachnodactyly (Parish, 1960). Rheumatoid and other inflammatory polyarthritides may cause widespread acquired hypermobility, as may neurological disorders such as poliomyelitis, tabes dorsalis, and myotonia congenita (Hass and Hass, 1958). "Flail joints" of neurological origin may result in episodes of traumatic synovitis and secondary osteo-arthritis-like changes.

Several rare diseases may show this feature, 
including the disorders of amino acid metabolism, homocystinuria (Schimke, McKusick, Huang, and Pollack, 1965) and hyperlysinaemia (Ghadimi, Binnington, and Pecora, 1965). Levine (1958) noted that hyperextensibility of the finger joints is common in children with rheumatic fever and Callegarini (1957) showed the same with joint range measurements.

The purpose of this paper is to describe a group of patients with joint laxity and musculoskeletal complaints, drawing attention to the hypermobility syndrome as an explanation for a variety of otherwise unexplained rheumatic complaints encountered in clinical practice.

\section{Material and Methods}

A series of 24 patients has been seen since 1960 at the Rheumatology Clinics of the Canadian Red Cross Memorial Hospital, Taplow; Hammersmith Hospital, London; Wrexham Park Hospital, Slough; and Heatherwood Hospital, Ascot. These patients had musculoskeletal complaints which the examiners at the time considered were due to generalized joint laxity.

They were recalled for further study of the course and nature of the complaints and for a search for any other physical characteristics common to the group. The patients were re-examined after an average period of 2 years by one of us (J.K.) and a full history was elicited, including a detailed account of the musculoskeletal symptoms. Family history of abnormal physique, joint dislocation, or other hypermobility associations was sought. The physical examination was made with particular regard to any of the stigmata of heritable connective tissue disorder, such as high arched palate, ocular and cardiac lesions, hyper-elastic skin, or arachnodactyly. The height, span, and pubis/heel dimensions were measured and the body build assessed. Relevant $x$ rays and laboratory investigations were reviewed and where hand $x$ rays were available, the Metacarpal Index (Sinclair, Kitchin, and Turner, 1960) was calculated by the method of Eldridge (1964) and compared with age-matched controls from population survey material (by courtesy of Dr. J. S. Lawrence).

The following subjects were studied for comparison:

(1) Nine first-degree relatives of hypermobile patients, ncluding a non-identical twin and his mother.

(2) Sixteen age-matched controls.

(3) Fifteen hospital patients convalescing from rheumatic fever.

Using a goniometer, the maximum movement of the following joint groups was measured and recorded according to the Neutral Zero Method as described by Cave and Roberts (1936):

(1) Active horizontal motion of the arms behind the coronal plane.

(2) Active hyperextension of the elbows.

(3) Active dorsiflexion of the wrists.

(4) Passive dorsiflexion of the third metacarpophalangeal joints.
(5) Passive approximation of the thumbs toward the forearms with the wrists in flexion.

(6) Supine hip flexion.

(7) Combined hip abduction in the supine position.

(8) Passive hyperextension of the knees.

In addition, the extent of passive ankle dorsiflexion and foot eversion was compared with the normal.

Analysis.-The results of the joint range measurements were analysed in two separate ways:

I. The criteria of joint hypermobility defined by Carter and Wilkinson (1964) were applied. The following joint movements are considered and if more than three of the five joint pairs are positive, then generalized hypermobility is present.

(a) Passive opposition of the thumb to the flexor aspect of the forearm.

(b) Passive hyperextension of the fingers so they lie parallel with the extensor aspect of the forearm.

(c) Ability to hyperextend the elbow more than $10^{\circ}$.

(d) Ability to hyperextend the knee more than $10^{\circ}$.

(e) An excess range of passive dorsiflexion of the ankle and eversion of the foot.

II. For each subject the measurements were compared with a generally accepted normal range in two age groups:

$\begin{array}{ccc}\text { Joint } \text { Group } & \text { Age 5-14 } & \text { Age 15+ } \\ \text { (1) Shoulders } & 30^{\circ} & 25^{\circ} \\ \text { (2) Elbows } & 5^{\circ} & 0^{\circ} \\ \text { (3) Wrists } & 90^{\circ} & 80^{\circ} \\ \text { (4) MCP } & 70^{\circ} & 60^{\circ} \\ \text { (5) Thumbs } & 175^{\circ} & 175^{\circ} \\ \text { (6) Hip flexion } & 95^{\circ} & 90^{\circ} \\ \text { (7) Hip total abduction } & 90^{\circ} & 85^{\circ} \\ \text { (8) Knees } & 5^{\circ} & 0^{\circ} \\ & \text { Feet and ankles } & \text { Subjective assessment. }\end{array}$

A scoring system was devised in which each measurement in excess of the normal counts one point toward a maximum of 17 . This second system seems superior to the first in that it includes the shoulders and hips, makes some allowance for age, and gives a fairer representation to the less severely hypermobile patients. The measurement of joint motion is subject to considerable technical error. This was reduced by one examiner making all the measurements and by the goniometer being read after it had been removed from the joint being measured. Body proportions were considered to be abnormal in an adult if the span differed from the height by 3 in. or the lower segment from the upper segment by 2 in. Sinclair and others (1960) suggested that these were suitable limits outside which the diagnosis of the Marfan's syndrome should be considered.

\section{Results}

Table I (opposite) shows hypermobility in patients and controls according to age.

The age at onset of complaints ranged from 3 to 58 years, symptoms commencing in threequarters of the patients before the age of 15 . The adults in this series were all female whereas the sexes were equally represented in children. The oldest male with the 
TABLE I

PROPORTIUN OF SUBJECTS WITH HYPERMOBILITY

\begin{tabular}{|c|c|c|c|c|c|c|c|}
\hline \multicolumn{5}{|c|}{ Subjects } & $\begin{array}{c}\text { Age } \\
\text { (yrs) }\end{array}$ & $\begin{array}{c}\text { Number of Patients with eight or more } \\
\text { Hypermobile Joints }\end{array}$ & $\begin{array}{c}\text { Number of Patients with Carter's } \\
\text { Score } 3 \text { or More }\end{array}$ \\
\hline \multirow{2}{*}{\multicolumn{5}{|c|}{ Hypermobile Patients with Symptoms }} & $5-14$ & $7 / 11$ & $8 / 11$ \\
\hline & & & & & $15+$ & $11 / 13$ & $1 / 13$ \\
\hline \multirow{2}{*}{\multicolumn{2}{|c|}{ First-degree Relatives }} & \multirow{2}{*}{\multicolumn{2}{|c|}{. $\quad \cdots$}} & \multirow[t]{2}{*}{. } & $5-14$ & $3 / 4$ & $4 / 4$ \\
\hline & & & & & $15+$ & $2 / 5$ & $1 / 5$ \\
\hline \multirow[t]{2}{*}{ Controls } & \multirow[t]{2}{*}{$\ldots$} & \multirow[t]{2}{*}{$\cdots$} & \multirow[t]{2}{*}{. } & \multirow[t]{2}{*}{. } & $5-14$ & $1 / 7$ & $2 / 7$ \\
\hline & & & & & $15+$ & $0 / 9$ & $0 / 9$ \\
\hline \multirow{2}{*}{\multicolumn{3}{|c|}{ Rheumatic Fever Patients.. }} & \multirow[t]{2}{*}{.. } & \multirow[t]{2}{*}{. } & $5-14$ & $2 / 12$ & $0 / 12$ \\
\hline & & & & & $15+$ & $0 / 3$ & $0 / 3$ \\
\hline
\end{tabular}

combination of joint laxity and symptoms was sixteen when symptoms ceased altogether. Symptomless hypermobility was found in one 5-year-old control and two children with rheumatic fever but in none of the adults.

Table II shows that the mean joint score in the hypermobility group was 9 (ranged 6 to 15), but a higher joint score did not always accompany severe complaints or a more widespread pattern of symptoms.

An unexpected finding was that rheumatic fever patients had a higher average joint score than the normal subjects. However, the observations of Callegarini (1957) were not confirmed, in that the extensibility of the metacarpopha!angeal joint $\left(60^{\circ}\right)$ was not significantly greater than that of agematched controls $\left(57^{\circ}\right)$.

The relatives (five mothers, three brothers, and a son) were also significantly hypermobile and two were found to have symptoms attributable to this. The son experienced joint pains after exertion and one mother had evidence of mild generalized osteoarthritis developing at the age of 44 . This further examination confirmed that the hypermobility was an isolated finding. In no patient was other evidence of hereditary connective tissue disorder, such as high palate, hyper-elastic skin, or easy bruising, detected. Further evidence against this condition being a forme fruste of Marfan's syndrome lay in the finding of normal body proportions on measurement and normal metacarpal indices. The combination of abnormal span and lower segment length occurred in only one patient, a hypermobile youth who had a normal metacarpal index $(7 \cdot 4)$ with no other clinical features of Marfan's syndrome. A raised metacarpal index may be more reliable evidence towards the diagnosis of Marfan's syndrome than an abnormal upper/lower segment ratio according to Eldridge (1964). Here the metacarpal indices were all within the normal range and showed the usual increase with age (Table III).

TABLE III AVERAGE METACARPAL INDEX

\begin{tabular}{|c|c|c|c|c|}
\hline \multirow{2}{*}{\multicolumn{3}{|c|}{ Series }} & \multicolumn{2}{|c|}{ Age (yrs) } \\
\hline & & & $5-14$ & $15+$ \\
\hline $\begin{array}{l}\text { Hypermobile Patients } \\
\text { Normal (England) }\end{array}$ & $\begin{array}{l}\ldots \\
\ldots\end{array}$ & $\begin{array}{l}\cdots \\
\cdots\end{array}$ & $\begin{array}{l}7 \cdot 4 \\
7 \cdot 6\end{array}$ & $\begin{array}{l}7 \cdot 9 \\
8 \cdot 0\end{array}$ \\
\hline
\end{tabular}

Upper limit of normal: Males 8·8; Females $9 \cdot 4$ (Eldridge, 1964).

TABLE II

MEAN HYPERMOBILITY

\begin{tabular}{|c|c|c|c|c|c|c|}
\hline \multicolumn{4}{|c|}{ Subjects } & $\begin{array}{r}\text { Age } \\
(\mathrm{yrs})\end{array}$ & $\begin{array}{c}\text { Average Number of } \\
\text { Hypermobile Joints per Patient }\end{array}$ & $\begin{array}{c}\text { Average Carter Score per } \\
\text { Patient }\end{array}$ \\
\hline \multirow{2}{*}{\multicolumn{2}{|c|}{ Hypermobile Patients with Symptoms }} & \multirow[t]{2}{*}{. } & \multirow[t]{2}{*}{. } & $5-14$ & $8 \cdot 7$ & $3 \cdot 0$ \\
\hline & & & & $15+$ & $10 \cdot 0$ & $2 \cdot 6$ \\
\hline \multirow[t]{2}{*}{ First-degree Relatives.. } & \multirow[t]{2}{*}{. $\quad \ldots$} & \multirow[t]{2}{*}{. } & \multirow[t]{2}{*}{. } & $5-14$ & $8 \cdot 3$ & $3 \cdot 0$ \\
\hline & & & & $15+$ & $7 \cdot 4$ & $1 \cdot 6$ \\
\hline \multirow[t]{2}{*}{ Controls } & \multirow[t]{2}{*}{. } & \multirow[t]{2}{*}{. } & \multirow[t]{2}{*}{. } & $5-14$ & $3 \cdot 8$ & $1 \cdot 4$ \\
\hline & & & & $15+$ & $1 \cdot 8$ & $0 \cdot 2$ \\
\hline \multirow[t]{2}{*}{ Rheumatic Fever Patients } & \multirow[t]{2}{*}{.. } & \multirow[t]{2}{*}{. } & \multirow[t]{2}{*}{$\cdots \quad \cdots$} & $5-14$ & $5 \cdot 9$ & $1 \cdot 4$ \\
\hline & & & & $15+$ & $3 \cdot 0$ & $0 \cdot 3$ \\
\hline
\end{tabular}


The physical appearance of the hypermobile patients was otherwise normal; they were not particularly tall or slender but several were noted to have poor muscular development.

In general the erythrocyte sedimentation rate was not raised, except transiently to about $30 \mathrm{~mm}$. $/ \mathrm{hr}$ (Westergren) during some episodes of traumatic synovitis. Neither was joint dislocation a prominent feature. One woman described recurrent shoulder dislocation with slight trauma in her youth and the daughter of another had congenital hip dislocation.

Musculoskeletal complaints varied widely in their duration, severity, and distribution (Table IV).

TABLE IV

MUSCULOSKELETAL COMPLAINTS IN 24 HYPERMOBILE PATIENTS

\begin{tabular}{|c|c|c|}
\hline Complaint & & No. of Cases \\
\hline $\begin{array}{l}\text { Muscle pains } \\
\text { Muscle and widespread joint pains } \\
\text { Isolated painless knee effusion } \\
\text { Joint pains (including four with kne } \\
\text { one with an elbow effusion). . }\end{array}$ & $\begin{array}{c}\cdots \\
\cdots \\
\ldots \\
\text { ee effusions ar } \\
\ldots\end{array}$ & $\begin{array}{r}2 \\
1 \\
2 \\
19\end{array}$ \\
\hline Total & .. & 24 \\
\hline
\end{tabular}

At one end of the scale were children with pains in one joint or muscle group for a year followed by complete recovery. At the other end were women with lifelong widespread joint pains sometimes with effusion, who developed degenerative joint changes in their 30s. In 21 of the 24 patients, pain was associated with over-use, more often following than accompanying it. Stiffness was a variable feature and damp weather was often incriminated as a factor. One third of the subjects considered themselves double-jointed. Whereas hypermobility is usually most prominent in the hands and wrists, symptoms predominated in the lower limbs (Table V).

TABLE V

SITES OF JOINT PAIN IN NINETEEN PATIENTS

\begin{tabular}{|c|c|c|c|c|c|c|c|c|}
\hline \multicolumn{8}{|c|}{ Site } & \multirow{2}{*}{$\frac{\text { No. of Cases }}{5}$} \\
\hline Widespre & & $\ldots$ & $\ldots$ & $\ldots$ & .. & $\ldots$ & $\ldots$ & \\
\hline Knees & $\ldots$ & .. & .. & $\ldots$ & $\ldots$ &.. & $\ldots$ & 11 \\
\hline Hands & \multicolumn{4}{|c|}{$\begin{array}{l}\text { (4 DJD thumb bases } \\
2 \text { wrists } \\
2 \text { MCP and PIP) .. }\end{array}$} & .. & . & .. & 8 \\
\hline Neck & \multicolumn{2}{|c|}{ (3 with DJD) } & $\ldots$ & .. & $\ldots$ & $\ldots$ & $\ldots$ & 5 \\
\hline Ankles & . & . & . & .. & $\ldots$ & $\ldots$ & . & 4 \\
\hline Back & \multicolumn{4}{|c|}{$\begin{array}{l}3 \text { lumbago and sciatica } \\
1 \text { coccydynia }\end{array}$} & .. & $\cdots$ & $\cdots$ & 4 \\
\hline$\overline{\text { Feet }}$ & \multicolumn{6}{|c|}{$\begin{array}{l}2 \text { painful flattened longitudinal arch } \\
1 \text { DJD first MTP }\end{array}$} & .. & 3 \\
\hline
\end{tabular}

Table VI shows the wide range of associated conditions encountered in the hypermobile patients.

TABLE VI

ADDITIONAL MUSCULOSKELETAL COMPLAINTS

\begin{tabular}{|c|c|c|c|c|c|c|}
\hline \multicolumn{6}{|c|}{ Complaints } & \multirow{2}{*}{$\frac{\text { No. of Cases }}{5}$} \\
\hline Degenerative jo & disease & . & .. & . & . & \\
\hline \multicolumn{3}{|c|}{ Dislocation (bilateral shoulders) } & $\cdots$ & $\cdots$ & $\cdots$ & 1 \\
\hline Miscellaneous & $\begin{array}{l}\text { Suprasp } \\
\text { Bicipita } \\
\text { Tennis } \\
\text { Golfer's } \\
\text { Painful }\end{array}$ & $\begin{array}{l}\text { tatu } \\
\text { tend } \\
\text { bow } \\
\text { elbo } \\
\text { chil }\end{array}$ & $\begin{array}{l}\text { ndinitis. } \\
\text { is } \\
\ldots \\
\text { tendon }\end{array}$ & $\begin{array}{l}\cdots \\
\cdots \\
\cdots \\
\cdots\end{array}$ & $\begin{array}{l}\cdots \\
\cdots \\
\cdots \\
\cdots\end{array}$ & $\begin{array}{l}2 \\
2 \\
1 \\
1 \\
1\end{array}$ \\
\hline
\end{tabular}

Cramplike muscle pains in the thighs, calves, and insteps occurred as the sole complaint in two children over several years, and gradually lessened as they approached puberty.

Case 1, a 10 year-old schoolboy, experienced nocturnal attacks of cramplike pains in the calves and instep between the ages of 3 and 9 years. At one time these occurred several times a week often after strenuous activity at school. At the time of examination, he had been free of pain for a year. He was hypermobile (nine lax joints out of seventeen with a Carter score of 4), both knees and elbows hyperextended by $20^{\circ}$ and the thumbs could be made to touch the forearms, but the feet and ankles were not lax. He was slender with normal height, $54 \frac{1}{2}$ in., span 56 in., lower segment 28 in., metacarpal index 7.9 .

Family.-The patient's non-identical twin brother was slightly smaller and lighter but also with normal proportions, height 53 in., span 52 in., lower segment 28 in, metacarpal index 7.6. He denied any musculoskeletal symptoms, although ten out of seventeen joints were hypermobile and the Carter score was 3. Both knees and ankes hyperextended by $10^{\circ}$.

His 32-year-old mother had complained for several years of aching in the joints following over-use. Typing would bring on wrist pain and a long walk caused pain in the knees and ankles which she said would swell for a day or so. Her body proportions were normal, height 65 in., span 65 in., lower segment 33 in., and measurement showed her to be mildly hypermobile in seven out of seventeen joints. The elbows and knees hyperextended by $5^{\circ}$ and the wrists dorsiflexed to $80^{\circ}$.

Two children aged 9 and 10 experienced episodes of pain in the front and medial aspects of the ankle joints without swelling after vigorous physical education at school. There was little discomfort during the activity but the pain at night was severe and they woke crying. In both cases the symptoms persisted for a year and then subsided completely, although the knees and ankles remained hypermobile.

Observed joint effusions had occurred in seven patients, involving the knee in six, being bilateral in 
one and usually recurrent. In two cases chronic knee effusion was the sole complaint, but generally the knee was the site of pain after over-use as well and sometimes other joints were involved. Knee pain was usually felt at the medial or lower border of the patella, occasionally posteriorly.

In two children chronic knee effusions still persisted 2 years after the onset and the affected knees lost their ability to hyperextend; both were unusually active in sport and recreation and the complaints coincided with a period of rapid growth and weight gain.

Case 2, a schoolgirl aged 12, developed a painful effusion into the right knee following unaccustomed high jumping during a sports meeting. The left knee had ached after use for the preceding few months. She had been taking penicillin prophylaxis after an attack of rheumatic fever without cardiac damage 7 years earlier.

The effusion still persisted 2 years later in spite of being twice aspirated and once injected with intra-articular corticosteroid. Percutaneous needle biopsy of the synovium showed normal synovial histology. Examination showed her to be strikingly hypermobile in thirteen joints with a Carter score of 4 . Both ankles and the left knee were lax but the affected knee did not hyperextend. Her physical appearance was normal, height 66 in., span 66 in., lower segment 33 in., metacarpal index 7.9. The enythrocyte sedimentation rate was $10 \mathrm{~mm}$./ hr (Westergren). She is an extremely active girl and an ardent ballet dancer which may account for the persistence of the effusion.

Some older female patients had multiple musculoskeletal complaints extending over many years, culminating in the development of degenerative joint changes at a premature age.

Case 3, a 45-year-old housewife, was the most strikingly hypermobile patient examined. She was slender with long arms, height 63 in., span 66 in., lower segment 32 in., and an asthenic build. Fifteen joints were lax with a Carter score of 4 . The knees hyperextended by $20^{\circ}$ and the elbows $15^{\circ}$. She could touch elbows behind her back and while standing touch the floor with her wrists. The enythrocyte sedimentation rate was normal and metacarpal index $8 \cdot 4$. All her life she was considered double-jointed. Since the age of 20 one knee had been painful and stiff after prolonged sitting and had once been the site of an effusion. The fingers became stiff and painful after knitting. Since the age of 33 years her neck movements had been painful and limited, the cervical $x$ ray showing disc narrowing $(\mathrm{C} 5,6,7)$ and degenerative changes. She was referred to the clinic because of recurrent "golfer's elbow". Her daughter was born with congenital dislocation of one hip.

Of the 24 hypermobile patients, five adult females showed clinical and radiological signs of degenerative joint disease. As shown in Table VII, the most common sites were the thumb bases and cervical spine and the age at onset of symptoms ranged from 33 to 56 years. Each of these five patients had in addition a history of joint pain or effusion in earlier life, but in two the complaints were so mild that it was symptoms from degenerative joint disease which first caused them to seek medical attention.

TABLE VII

DEVELOPMENT OF SYMPTOMS DUE TO OSTEO-ARTHRITIS IN FIVE HYPERMOBILE PATIENTS

\begin{tabular}{c|lll|l}
\hline \multirow{2}{*}{ No. of Cases } & \multicolumn{2}{|c|}{ Site } & Age at Onset (yrs) \\
\cline { 2 - 4 } & \multicolumn{2}{|c}{ Aarpometacarpal joints } & $\ldots$ & $56,53,41,38$ \\
3 & Cervical spine & $\ldots$ & $\ldots$ & $54,39,33$ \\
2 & Patello-femoral & $\ldots$ & $\ldots$ & 54,45 \\
1 & Elbow $\ldots$ & $\ldots$ & $\ldots$ & 38 \\
1 & First MTP & $\ldots$ & $\ldots$ & 36 \\
1 & Mild generalized $\ldots$ & $\ldots$ & 52 \\
\hline
\end{tabular}

Case 4, a 57-year-old female secretary, had developed effusions of one knee on five occasions in the previous 10 years, each following strenuous gardening or work involving kneeling. In between effusions she had pains at the lower end of each patella on exercise and on descending stairs. She attended the clinic when the thumb bases became painful at the age of 56 . She was a tall slender woman, height 67 in., span 68 in., lower segment 34 in., metacarpal index $7 \cdot 3$. Thirteen joints were lax and the Carter score 4. From her earliest recollection she had been proud of being double-jointed, she would bend her thumbs onto the forearm or squat on the floor and then lie flat with ease until about the age of 30. Until her teens she was an active ballet dancer and wished to turn professional but became too tall for it.

Her mother had generalized osteo-arthritis and by description was probably hypermobile. Clinical and radiological examination confirmed the presence of patello-femoral and carpo-metacarpal osteo-arthritis. Notwithstanding she could still bend her thumb forward parallel to the forearm.

\section{Discussion}

The isolated joint hypermobility in these patients is considered to be the result of generalized familial ligamentous laxity. This study supports the opinion that this condition represents the extreme of a wide normal variation in joint mobility. Another view is that isolated ligamentous laxity is a mild mesenchymal developmental disorder which lies at one end of a spectrum of heredofamilial connectivel tissue disease with the fully-developed picture of Marfan's syndrome and the Ehlers-Danlos syndrome at the other (Brown and Rose, 1666). Although hypermobility is relatively common in the general population, depending on the criteria chosen for diagnosis, reports of musculoskeletal complaints are infrequent. However, as most 
symptoms are mild and self-limiting so that subjects may not seek medical attention, the overall incidence of complaints due to hypermobility is likely to be much greater than hitherto recognized. In this study many of the patients attended the clinic because of a family history of rheumatoid arthritis, because an intercurrent sore throat raised the question of rheumatic fever, or through being members of a medical family or hospital staff. At the present time the diagnosis of this condition is essentially clinical combined with an awareness of the family history. The diagnosis and classification of the hereditary connective tissue disorders have as yet not been facilitated by histological or biochemical studies including recent work on hydroxyproline and mucopolysaccharide metabolism.

The management commences with reassurance as to the absence of serious disease. When an explanation of the complaints is given many patients do not again seek medical attention. Activity which precipitates symptoms should be avoided if possible and, where the musculature is poor, which is common, swimming is encouraged as regular exercise.

Most young subjects will grow out of their complaints altogether. Others will develop premature degenerative joint disease particularly in the cervical spine, thumb base, and patello-femoral articulation. In this study this complication did not appear before the third decade.

\section{Summary}

A reassessment was made of 24 patients who had presented with various musculoskeletal complaints and who had been found to have generalized joint laxity; the latter was thought to be responsible for their complaints.

The ranges of joint movement, body proportions, and metacarpal indices were measured and compared with other family members, rheumatic fever patients, and normal controls.

Generalized familial joint laxity was found to occur in this group of patients without any other features of hereditary connective tissue disorder. The wide range of associated symptoms is described. The hypermobility syndrome appears to predispose to the premature development of degenerative joint disease.

It is important to recognize this syndrome, since a firm diagnosis and reassurance may help the patient considerably and save a great deal of anxiety and medical time.

\section{DISCUSSION}

DR. J. S. LAWRENCE (Manchester): In our family study of rheumatoid arthritis, we examined 600 first-degree relatives of patients with arthritis and found that hypermobility was present about $2 \frac{1}{2}$ times as often in these relatives as in the control population sample. I do not know whether we can draw any conclusions from this, but it suggests that there is a genetic factor in rheumatoid arthritis which is concerned more with the connective tissue structure than with any abnormality in the immunologically competent cells. Have you come across any cases of rheumatoid arthritis in the relatives of these patients?

DR. KIRK: Dr. Ansell tells me there was one.

DR. H. L. F. CURrey (London): I wonder if you could comment on the racial incidence of this laxity? There is a strong clinical impression that hypermobility of joints is greater in people of African Negro origin than in those of European origin.

DR. KIRK: I think this is quite true. These patients were all born in Great Britain and living locally. It is my impression that Indians and Pakistanis do have a greater degree of joint laxity, and Prof. Bywaters has told me that he found the same among the patients he saw in Egypt.

Prof. Bywaters: I think this study is useful firstly because hypermobility is a factor which may possibly enter into the genesis, severity, or progression of other joint diseases, and secondly because in individual patients it is always more satisfactory for the clinician to be able to give a positive diagnosis. These patients often masquerade under other labels, rheumatoid arthritis, fibrositis, psychoneurosis, etc., which is unsatisfactory. I recognized the first one in about 1950; he was a young doctor, whose symptoms had been ascribed to many different categories by many different doctors. While not much can be done therapeutically, it is a great psychological help to the patient (and the doctor also) to recognize the real origin of the symptoms.

DR. A. G. S. Hill (Stoke Mandeville): Was there any evidence of discomfort or clicking in the temporomandibular joint?

DR. KIRK: We received no complaints of this.

\section{REFERENCES}

Brown, A. Rowatt, and Rose, B. S. (1966). N. Z. med. J., 65, 449 (Familial precocious polyarticular osteo-arthrosis of chondrodysplastic type).

Callegarini, U. (1957). Bull. St. Francis Hosp. (N.Y.), 14, 32 (Clinical study on the hyper-extensibility of fingers in rheumatic children).

Carter, C., and Sweetnam, R. (1958). J. Bone Jt Surg., 40B, 664 (Familial joint laxity and recurrent dislocation of the patella). (1960). Ibid., 42B, 721 (Recurrent dislocation of the patella and of the shoulder). and Wilkinson, J. (1964). Ibid., 46B, 40 (Persistent joint laxity and congenital dislocation of the hip). 
Cave, E. F., and Roberts, S. M. (1936). Ibid., 18, 455 (A method for measuring and recording joint function).

Eldridge, R. (1964). Arch. intern. Med., 113, 248 (The metacarpal index).

Finkelstein, H. (1916). N. Y. med. J., 104, 942 (Joint hypotonia).

Ghadimi, H., Binnington, V. I., and Pecora, P. (1965). New Engl. J. Med., 273, 723 (Hyperlysinemia associated with retardation).

Hass, J., and Hass, R. (1958). J. Bone Jt Surg., 40A, 663 (Arthrochalasis multiplex congenita).

Key, J. A. (1927). J. Amer. med. Ass., 88, 1710 (Hypermobility of joints as a sex-linked hereditary characteristic).

Levine, S. A. (1958). " "Clinical Heart Disease”, 5th ed., p. 12. Saunders, Philadelphia.

Massie, W. K., and Howorth, M. B. (1951). J. Bone Jt Surg., 33A, 190 (Congential dislocation of the hip. Part III. Pathogenesis).

McKusick, V. A. (1966). "Heritable Disorders of Connective Tissue", 3rd ed., p. 47. Mosby, St. Louis.

Parish, J. G. (1960). Proc. roy. Soc. Med., 53, 515 (Skeletal syndromes associated with arachnodactyly).

Schimke, R. N., McKusick, V. A., Huang, T., and Pollack, A. D. (1965). J. Amer. med. Ass., 193, 711 (Homocystinuria).

Sinclair, R. J. G., Kitchen, A. H., and Turner, R. W. D. (1960). Quart. J. Med., 29, 19 (The Marfan :syndrome).

Sturkie, P. D. (1941). J. Hered., 32, 232 (Hypermobile joints in all descendants for two generations).

Sutro, C. J. (1947). Surgery, 21, 67 (Hypermobility of bones due to "overlengthened" capsular and ligamentous tissues; a cause for recurrent intra-articular effusions).

Le syndrome d'hypermobilité. Des symptômes locomoteurs associés à l'hypermobilité articulaire généralisée.

RÉSUMÉ

On ré-examina 24 malades présentant de différents symptômes du système locomoteur chez qui on avait trouvé un relâchement articulaire généralisé et attribué les symptômes à ce relâchement. On détermina l'amplitude du mouvement articulaire, la conformation corporelle et les indices métacarpiens et on compara ces données avec celles obtenues chez d'autres membres de la famille, chez des patients atteints de rhumatisme articulaire aigu et chez des sujets normaux.

On trouva que le relâchement articulaire généralisé familial survient dans ce groupe de patients en l'absence de tout signe de désordre héréditaire du tissu conjonctif. On décrit un grand nombre des symptômes y associés. Le syndrome d'hypermobilité semble prédisposer ses porteurs au développement précoce d'une maladie articulaire dégénérative.

Il est important qu'on reconnaisse ce syndrome, car un diagnostic ferme permet de rassurer le malade et facilite la tâche du médecin.
El sindrome de hipermovilidad. Síntomas locomotores asociados con una hipermovilidad articular generalizada.

\section{SUMARIO}

Se volvieron a examinar 24 enfermos con varios síntomas del sistema locomotor en los cuales se había encontrado una laxitud articular generalizada y atribuido estos síntomas a ella. Se determinaron la amplitud del movimiento articular, la conformación del cuerpo y los indicios metacarpianos y se compararon estos datos con los obtenidos en otros miembros de la familla, en enfermos con ruematismo poliarticular agudo $y$ en sujetos normales.

Se halló que la laxitud articular generalizada familiar ocurre en este grupo de pacientes sin evidencia alguna de trastorno hereditario del tejido conectivo. Se describen los numerosos síntomas asociados. El síndrome de hipermovilidad parece predisponer al desarrollo prematuro de una enfermedad articular degenerativa.

El reconocimiento de este síndrome es importante, ya que un diagnóstico firme conforta el paciente y facilita la tarea del médico. 